\title{
SYNTHESIS OF BIOLOGICALLY ACTIVE CHALCON ANALOGUES VIA CLAISEN-SCHMIDT CONDENSATION IN SOLVENT-FREE CONDITIONS: SUPPORTED MIXED ADDENDA HETEROPOLY ACID AS A HETEROGENEOUS CATALYST
}

\author{
EZZAT RAFIEE* AND FARZANEH RAHIMI
}

Faculty of Chemistry, Razi University, Kermanshah, 67149, Iran

(Received: March 14, 2013 - Accepted: May 20, 2013)

\begin{abstract}
Biologically active chalcones were synthesized via Claisen-Schmidt condensation of aldehydes with different ketones in solvent-free conditions using $\mathrm{H}_{5} \mathrm{PMo}_{10} \mathrm{~V}_{2} \mathrm{O}_{40}$ supported on $\mathrm{SiO}_{2}$ as a reusable heterogeneous catalyst with excellent reusability.
\end{abstract}

Keywords: Chalcone, Claisen-Schmidt condensation, mixed addenda, heteropoly acid, heterogeneous catalyst.

\section{INTRODUCTION}

Chalcones belonging to flavonoid family have displayed a broad spectrum of biological activities, among which antimalarial ${ }^{1}$, anticancer ${ }^{2}$, antimitotic ${ }^{3}$, antibacterial $^{4}$, antiADIS ${ }^{5}$, antihyperglycemic ${ }^{6}$ activities have been reported. These compounds are of high interest due to their use as a key precursor in the synthesis of many biological important heterocycles such as benzothiazepine ${ }^{7}$, pyrazolines $^{8}$ and flavones 9 . Thus, the organic/pharmaceutical chemists worldwide have paid more attention to the synthesis of chalcones. Chalcones could be obtained via Claisen-Schmidt condensation carried out in basic or acidic media under homogenous conditions ${ }^{10}$. There are many drawbacks under homogenous conditions including catalyst recovery and waste disposal problems. Heterogeneous processes are industrially favor catalytic processes in view of the ease of handling, simple work- up and regenerability. There are different kind of catalysts which have been used for the Claisen-Schmidt condensation, including Lewis acids ${ }^{11}$, Brönsted acid ${ }^{12}$, solid $\operatorname{acid}^{13}$, solid bases $^{14}$, and other catalysts with more or less success ${ }^{15,16}$. The increasing concern about the tight legislation on the maintenance of greenness in synthetic strategy led us to develop a method using green catalyst that is active in solvent-free conditions as an alternative to volatile organic solvents. Here we have studied the solvent-free Claisen- Schmidt condensation reaction using heteropoly acids (HPAs) as solid acid catalysts that are metal- oxygen clusters and they have attracted much attention as catalyst in organic reactions because of their high Brönsted acidity and redox properties ${ }^{17,18}$.

\section{EXPERIMENTAL}

\section{General}

The reagents and solvents used in this work were obtained from Fluka, Aldrich or Merck and were used without further purification. The commercial Aerosil silica $\left(\mathrm{S}_{\mathrm{BET}}, 311 \mathrm{~m}^{2} \mathrm{~g}^{-1}\right.$; pore volume, $\left.1.7 \mathrm{~cm}^{3} \mathrm{~g}^{-1}\right)$ from Degussa was used. The catalyst sample was characterized with a scanning electron microscope (SEM) (Philips XL 30 and S-4160) with gold coating.

\section{Typical procedure for Claisen-Schmidt condensation}

To a mixture of ketone $(1 \mathrm{mmol})$ and aldehyde $(2 \mathrm{mmol}$ for Table $2 ; 1$ mmol for Table 3), $\mathrm{Mo}_{10} \mathrm{~V}_{2} / \mathrm{SiO}_{2}$ (produced $40 \mathrm{wt} . \%$ : of $\mathrm{Mo}_{10} \mathrm{~V}_{2}$ to silica ${ }^{19}, 32.5$ wt.\% from ICP result, typically, the Mo content from ICP was slightly lower than expected from the preparation stoichiometry) $(0.06 \mathrm{~g}, 0.085 \mathrm{~mol} \%$ of $\mathrm{Mo}_{10} \mathrm{~V}_{2}$ to ketone as substrate) was added and crushed at $50{ }^{\circ} \mathrm{C}$ for appropriate time. Completion of the reaction was monitored by TLC, using n- hexane/ ethylacetate (10:4) as eluent. After completion of the reaction, $2 \times 10 \mathrm{~mL}$ of ether was added to the mixture and filtered off. Catalyst was washed with ether and dried for reusing. The solvent of the filtrate was evaporated then followed by chromatography to obtained pure products. Spectroscopic data of the products matched well with those in the literature ${ }^{20-23}$ and analytical data for new compounds are presented below:

2,6-Bis-naphthalen-2-ylmethylene-cyclohexanone $\left(2 \mathrm{e}, \mathrm{C}_{28} \mathrm{H}_{22} \mathrm{O}\right)$ Yellow solid; Mp: 281-282 ${ }^{\circ} \mathrm{C},{ }^{1} \mathrm{H}$ NMR (200 MHz; $\mathrm{CDCl}_{3}$, TMS) $\delta 1.45(\mathrm{~m}, 2 \mathrm{H}), 2.78$ (t, 4H, J=5.6), 7.28-7.58 (m, 12H), $7.61(\mathrm{~s}, 2 \mathrm{H}) ;{ }^{13} \mathrm{C}$ NMR $\left(200 \mathrm{MHz}^{\mathrm{C}} \mathrm{CDCl}_{3}\right)$ $\delta$ 24.4, 28.1, 122.6, 125.5, 126.2, 127.4, 129.2, 133.0, 132.3, 133.8, 143.4, 149.3, 190.2; IR $\left(\mathrm{KBr}, \mathrm{cm}^{-1}\right) 1660(\mathrm{C}=\mathrm{O}), 1622(\mathrm{C}=\mathrm{C}) \mathrm{cm}^{-1} ; \mathrm{MS} \mathrm{m} / \mathrm{z} 374.16$; Anal Calcd. for $\mathrm{C}_{28} \mathrm{H}_{22} \mathrm{O}$ (374.17): C, 89.81; H, 5.92. Found: C, 89.83; H, 5.90.

4-Methyl-2,6-bis-naphthalen-2-ylmethylene-cyclohexanone $\left(2 \mathbf{f}, \mathrm{C}_{29} \mathrm{H}_{24} \mathrm{O}\right)$ Yellow solid; Mp: $288-290{ }^{\circ} \mathrm{C},{ }^{1} \mathrm{H}$ NMR $\left(200 \mathrm{MHz}\right.$; CDCl, TMS): $\delta 7.69^{24}(\mathrm{~s}$, $2 \mathrm{H}), 1.51(\mathrm{~d}, 3 \mathrm{H}, \mathrm{J}=6.2), 1.63(\mathrm{~m}, 1 \mathrm{H}), 2.81(\mathrm{~m}, 4 \mathrm{H}), 7.29-7.56(\mathrm{~m}, 12 \mathrm{H}) ;{ }^{13} \mathrm{C}$
NMR (200 MHz, $\left.\mathrm{CDCl}_{3}\right) \delta 21.5,28.3,35.2,122.0,125.4,126.2,127.4,128.3$, 131.2, 132.7, 135.6, 142.8, 148.1, 190.2; IR $(\mathrm{KBr}) 1660(\mathrm{C}=\mathrm{O}), 1620(\mathrm{C}=\mathrm{C})$ $\mathrm{cm}^{-1}$; MS m/z 388.16; Anal Calcd. for $\mathrm{C}_{29} \mathrm{H}_{24} \mathrm{O}$ (388.18): C, 89.66; H, 6.23. Found: C, 89.63; H, 6.25 .

\section{RESULTS AND DISCUSSION}

In the beginning of the study, cyclohexanone and benzaldehyde were used as model reactants in order to find the optimum reaction conditions by ClaisenSchmidt condensation using HPAs as catalysts (Scheme 1).

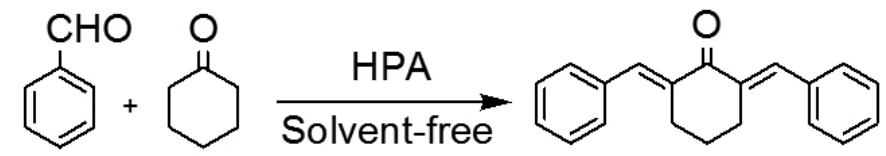

\section{Scheme 1. Model reaction.}

Without the addition of the catalyst, no product was formed even after $2 \mathrm{hrs}$. Various types of mixed addenda catalysts with different ratio of molybdenum to vanadium were evaluated for the synthesis of chalcones. $\mathrm{H}_{5} \mathrm{PMo}_{10} \mathrm{~V}_{2} \mathrm{O}_{40}\left(\mathrm{Mo}_{10} \mathrm{~V}_{2}\right)$ showed excellent reactivity among different kinds of the catalysts (Table 1 ).

Table 1. Synthesis of chalcones using different HPA catalysts.

\begin{tabular}{|c|c|c|c|}
\hline Entry & Catalyst $^{\mathrm{a}}$ & Time (min) & ${\text { Yield }(\%)^{\mathrm{b}}}^{\mathrm{b}}$ \\
\hline 1 & - & 120 & 0 \\
\hline 2 & $\mathrm{Mo}_{10} \mathrm{~V}_{2}$ & 15 & 98 \\
\hline 3 & $\mathrm{Mo}_{9} \mathrm{~V}_{3}$ & 25 & 93 \\
\hline 4 & $\mathrm{Mo}_{8} \mathrm{~V}_{4}$ & 40 & 95 \\
\hline 5 & $\mathrm{Mo}_{10} \mathrm{~V}_{2} / \mathrm{SiO}_{2}$ & 10 & 98 \\
\hline 6 & $\mathrm{Mo}_{10} \mathrm{~V}_{2} / \mathrm{SiO}_{2}$ & 50 & $10^{\mathrm{c}}$ \\
\hline
\end{tabular}

a) Isolated yield.

b) Reaction conditions: cyclohexanone ( $1 \mathrm{mmol})$, benzaldehyde $(2 \mathrm{mmol})$, catalyst $(0.06 \mathrm{~g})$, solvent-free, $50{ }^{\circ} \mathrm{C}$.

c) Reaction proceed at room temperature.

HPAs with Keggin structures are flexible in their acid strength and have low toxicity and fairly high thermal stability, so they are excellent and versatile catalysts for a wide variety of organic reactions in both homogeneous and heterogeneous media ${ }^{24,25}$. By immobilization of HPAs into convenient carriers, the reaction easily carry out in a heterogeneous which has some advantages like increase the accessibility to the acid sites and control solid acid strength. Moreover, wastes are not produced, helping to incorporate in clean technologies. Porous silica is one of the solids that has been mainly used for supporting HPAs in various acid catalyzed reactions so here silica was used as support for $\mathrm{Mo}_{10} \mathrm{~V}_{2}$ and as shown in Table 1, the minimum of the reaction time was need when this catalyst used in the model reaction that is due to increase in the surface area of the catalyst. When the reaction was carried out in room 
temperature, there is no significant progress in the reaction so reaction was carried out in $50{ }^{\circ} \mathrm{C}$.

The morphological feature of the $\mathrm{Mo}_{10} \mathrm{~V}_{2} / \mathrm{SiO}_{2}$ catalyst was investigated by SEM techniques. Fig. 1(a) shows the SEM micrograph of the catalyst. The particles are regular in shape and dispersed uniformly. Wavelength dispersive $\mathrm{X}$-ray (WDX) image studied that is the map of individual elements of $\mathrm{Si}$, Mo and $\mathrm{V}$ elements in cross-section were shown in Fig. 1(b). It showed an excellent uniform distribution of $\mathrm{Mo}_{10} \mathrm{~V}_{2}$ on $\mathrm{SiO}_{2}$ surface.

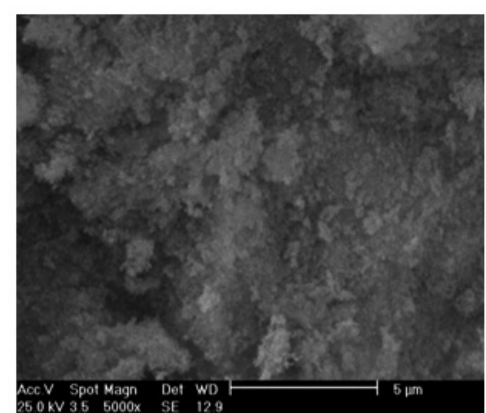

(a)

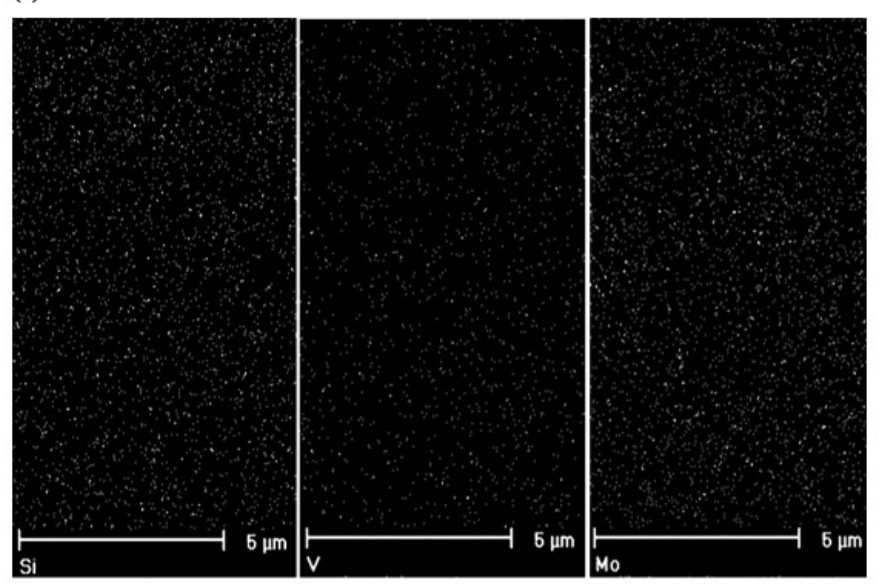

(b)

Fig. 1. SEM images of (a) $\mathrm{Mo}_{10} \mathrm{~V}_{2} / \mathrm{SiO}_{2}$ and (b) elemental maps of $\mathrm{Si}$, Mo and $\mathrm{V}$ atoms of $\mathrm{Mo}_{10} \mathrm{~V}_{2} / \mathrm{SiO}_{2}$ catalyst.

To optimize the catalyst loading model reaction was performed with different amounts of the catalyst and the best result was obtained with $0.06 \mathrm{~g}$ of $\mathrm{Mo}_{10} \mathrm{~V}_{2} / \mathrm{SiO}_{2}$ as shown in Fig. 2 .

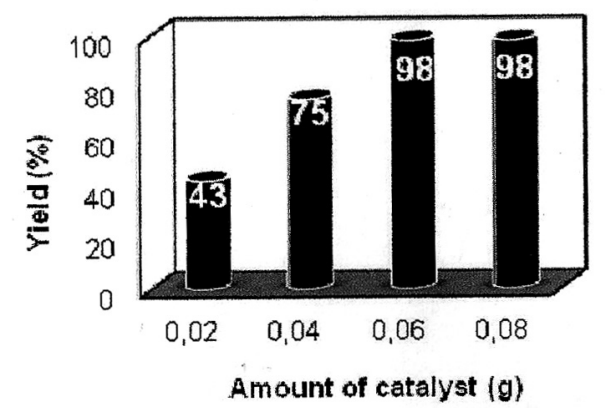

Fig. 2. Effect of the amount of the catalyst in the model reaction after 10 $\min$.

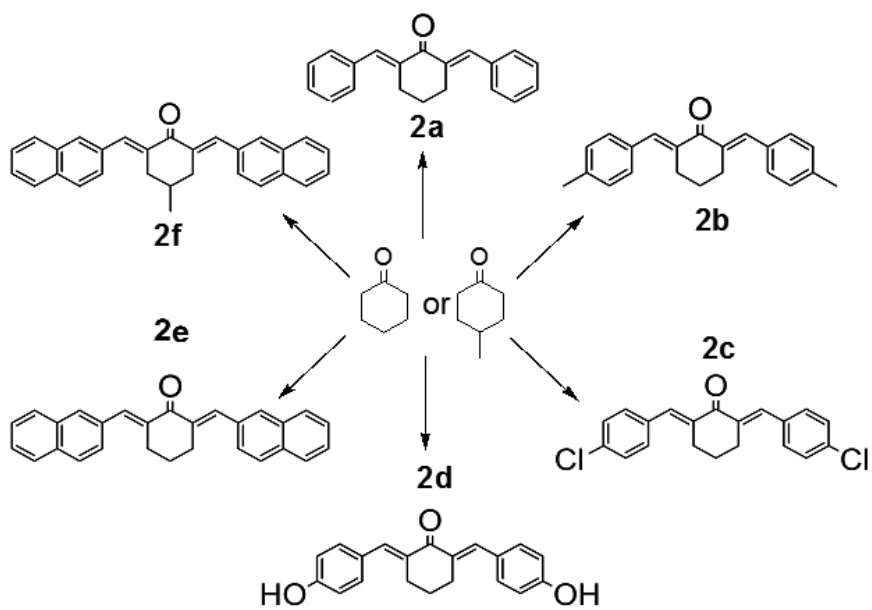

Scheme 2. Synthesis of cahcones with cyclic ketones.

To investigate the generality of the method a variety of aldehydes were used in the optimized reaction conditions with cyclohexanone and 4-methylcyclohexane as cyclic ketones (Scheme 2). In most cases the reaction proceeded smoothly to produce the corresponding chalcones. The reactions were found to be clean and the products were obtained in excellent yields without the formation of any side products (Table 2).

Table 2. Synthesis of different chalcones from cyclic ketones using $\mathrm{Mo}_{10} \mathrm{~V}_{2} / \mathrm{SiO}_{2}$ as catalyst.

\begin{tabular}{|c|c|c|c|c|c|c|}
\hline \multirow{2}{*}{ Entry } & \multirow{2}{*}{ Aldehyde } & \multirow{2}{*}{ Product } & \multirow{2}{*}{$\begin{array}{l}\text { Time } \\
(\mathrm{min})\end{array}$} & \multirow{2}{*}{$\begin{array}{l}\text { Yield } \\
(\%)^{\mathrm{a}}\end{array}$} & \multicolumn{2}{|c|}{$\mathrm{mp}\left({ }^{\circ} \mathrm{C}\right)$} \\
\hline & & & & & Observed & Reported \\
\hline 1 & & $2 \mathbf{a}$ & 10 & 98 & $116-117$ & $115-117^{25}$ \\
\hline 2 & & $2 b$ & 20 & 96 & $168-170$ & $170-171^{25}$ \\
\hline 3 & & $2 \mathrm{c}$ & 20 & 97 & $144-146$ & $147-148^{25}$ \\
\hline 4 & & 2d & 30 & 95 & $288-290$ & $289-291^{25}$ \\
\hline 5 & & $2 e$ & 25 & 94 & $281-282$ & - \\
\hline 6 & & $2 f$ & 40 & 93 & $288-290$ & - \\
\hline
\end{tabular}

a) Isolated yield.

Encourage by these results, we decided to use aromatic ketones (Scheme 3 ) and as we expected the products were obtained with high yields and without any byproducts (Table 3 ).

In the cases of $\mathbf{3 a - 3} \mathbf{h}$ products, ${ }^{1} \mathrm{H}$ NMR spectral data clearly indicated that the compounds were geometrically pure and were configured trans $\left(\mathrm{J}_{\mathrm{Ha}}\right.$ $=15-16 \mathrm{~Hz})$. In other reactions (2a-2f products), we obtained only the $E, E$ isomer. In the spectra of compounds, the signals for the protons of the $\mathrm{CH}=$ group appear at $\delta 7.41-7.81$. It is known ${ }^{26-28}$ that the $Z$ isomers are characterized by the chemical shifts at $\delta \sim 6.8$, whereas the signals for the $E$ isomers should appear at higher field than $7.2 \mathrm{ppm}$.

Reaction of 1-methyl-4-pipridone as a heteroaromatic ketone with 4-cholorobenzaldehyde show $87 \%$ of 3,5-bis-(4-chloro-benzylidene)-1methyl-piperidin-4-one after $1 \mathrm{~h}^{29}$. 


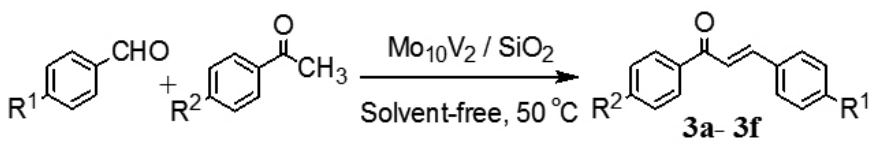

Scheme 3.Claisen- Schmidt condensation reaction with aromatic ketones.

Table 3. Synthesis of different chalcones from aromatic ketones using $\mathrm{Mo}_{10} \mathrm{~V}_{2} / \mathrm{SiO}_{2}$ as catalyst.

\begin{tabular}{|c|c|c|c|c|c|c|c|}
\hline \multirow{2}{*}{ Entry } & \multirow{2}{*}{$\mathrm{R}^{1}$} & \multirow{2}{*}{$\mathrm{R}^{2}$} & \multirow{2}{*}{ Product } & \multirow{2}{*}{ Time (min) } & \multirow{2}{*}{ Yield $(\%)^{\mathrm{a}}$} & \multicolumn{2}{|c|}{$\mathrm{mp}\left({ }^{\circ} \mathrm{C}\right)$} \\
\hline & & & & & & Observed & Reported \\
\hline 1 & - & - & $3 a$ & 20 & 96 & $54-56$ & $54-57^{21}$ \\
\hline 2 & $\mathrm{Cl}$ & - & $3 \mathbf{b}$ & 24 & 98 & $111-112$ & $111-113^{21}$ \\
\hline 3 & $\mathrm{CH}_{3}$ & - & $3 c$ & 45 & 97 & $97-98$ & $97-98^{22}$ \\
\hline 4 & $\mathrm{OH}$ & - & $3 d$ & 20 & 95 & $178-180$ & $181-183^{23}$ \\
\hline 5 & - & $\mathrm{Cl}$ & $3 e$ & 45 & 90 & $98-100$ & $100-101^{23}$ \\
\hline 6 & - & $\mathrm{OH}$ & $3 f$ & 25 & 95 & $172-174$ & $173-174^{23}$ \\
\hline 7 & $\mathrm{NO}_{2}$ & - & $3 g$ & 40 & 91 & $158-160$ & $159-160^{26}$ \\
\hline 8 & $\mathrm{OMe}$ & $\mathrm{NO}_{2}$ & $3 \mathrm{~h}$ & 30 & 92 & 193-194 & $191-192^{21}$ \\
\hline
\end{tabular}

a) Isolated yield.

The catalyst shows reusability in this reaction and the catalytic activity of the catalyst has not significant decrease even after four runs and it shows that $\mathrm{Mo}_{10} \mathrm{~V}_{2} / \mathrm{SiO}_{2}$ is a good catalyst according the economics of reaction and green chemistry purposes Fig. 3.

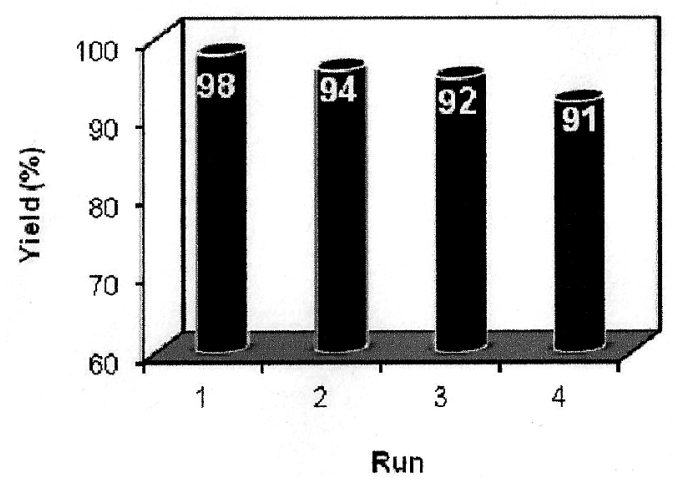

Fig. 3. Reusability of the $\mathrm{Mo}_{10} \mathrm{~V}_{2} / \mathrm{SiO}_{2}$ in model reaction after $10 \mathrm{~min}$.

The proposed mechanism is shown as Scheme 4. $\mathrm{Mo}_{10} \mathrm{~V}_{2} / \mathrm{SiO}_{2}$ activates both of the carbonyl groups. The chalcones are formed with excellent chemoselectivity. No side products are formed such as product of decomposition, self-condensation or Michael addition.

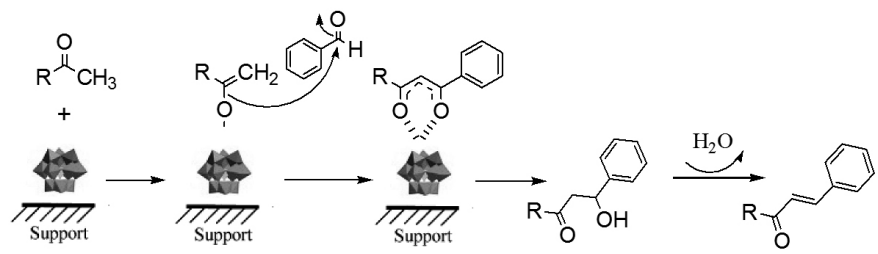

Scheme 4. Suggested mechanism of the Claisen-Schmidt condensation.

\section{CONCLUSIONS}

An efficient heterogeneous HPA-based catalyst has been prepared by immobilization of $\mathrm{Mo}_{1} \mathrm{~V}_{2}$ on commercial Aerosil silica. WDX analysis showed that the $\mathrm{Mo}_{10} \mathrm{~V}_{2}$ particles were uniformly distributed on support surface. This catalyst was successfully used in the synthesis of chalcones via ClaisenSchmidt condensation of aldehydes with different ketones in solvent-free conditions. The reactions were found to be clean and the products were obtained in excellent yields from aromatic and cyclic ketones without the formation of any side products. Excellent yields, selectivities, and environmentally friendly procedure, with low cost, easy preparation with high reusability and handling of catalyst are some of salient advantages of this method.

\section{ACKNOWLEDGEMENTS}

We thank the Razi University Research Council for support of this work.

\section{REFERENCES}

1. M. Liu, P. Wilairat, M. L. Go, J. Med. Chem. 44, 4443, (2001)

2. B. M. Ku, H. W. Ryu, Y. K. Lee, J. Ryu, J. Y. Jeong, J. Choi, K. H. Park, S. S. Kang, Biochem. Biophys. Res. Commun. 402, 525, (2010)

3. S. Ducki, R. Forrest, J .A. Hadfield, A. Kendall, N. J. Lawrence, A. McGown, T. D. Rennison, Bioorg. Med. Chem. Lett. 8, 1051, (1998)

4. D. Batovska, S. Parushev, B. Stamboliyska, I. Tsvetkova, M. Ninova, H. Najdenski, Eur. J. Med. Chem. 44, 2211, (2009)

5. C. Pouget, C. Fagnere, J. Basly, P. G. Habrioux, A. J. Chulia, Bioorg. Med. Chem. Lett. 12, 1059, (2002)

6. P. Shulka, A. B. Singh, A. K. Srivastava, R. Pratap, Bioorg. Med. Chem. Lett. 17, 799, (2007)

7. G. Sharma, R. Kumar, A. K. Chakraborti, Tetrahedron Lett. 49, 4269, (2008)

8. J. Quiroga, Y. Daiz, B. Insuasty, R. Abonia, M. Nogueras, J. Cobo, Tetrahedron Lett. 21, 2928, (2010)

9. B.A. Bohm Introduction to Flavonoid, Harwood Academic, Amesterdam, 1998.

10. N. Dhar Chemistry of Chalcones and related compounds, Wiley, New York, 1981.

11. A. Kumar, J. Mol. Catal. A: Chem. 247, 206, (2007)

12. S. Shylesh, P. P. Samuel, Ch. Srilakshmi, R. Parischa, A. P. Singh, J. Mol. Catal. A: Chem. 274, 153, (2007)

13. W. Li, K. Xu, L. Xu, J. Hua, F. Maa, Y. Guo, Appl. Surf. Sci. 256, 3183, (2010)

14. T. Selvamani, A. Sinhamahapatra, D. Bhattacharjya, I. Mukhopadhyay, Mater. Chem. Phys. 129, 853, (2011)

15. R. Ballini, G. Bosica, R. Maggi, M. Ricciutelli, P. Righi, G. Sartorib, R. Sartoriob, Green Chem. 3, 178, (2001)

16. A. Solhy, R. Tahir, S. Sebti, R. Skouta, M. Bousmina, M. Zahouily, M. Larzek, Appl. Catal. A: Gen. 374, 189, (2010) 
17. E. Rafiee, M. Khodayari, M. Joshaghani, Can. J. Chem. 89, 1533, (2011)

18. J. Goldberg, D. Kumar, G. N. Sastry, G. Leitus, R. Neumann, J. Mol. Catal. A: Chem. 356, 152, (2012)

19. E. Rafiee, Z. Zolfaghari, M. Joshaghani, S. Eavani, Appl. Catal. A: General 365, 287, (2009)

20. G. Liang, S. Yang, H. Zhou, L. Shao, K. Huang, J. Xiao, Z. Huang, X. Li, Eur. J. Med. Chem. 44, 915, (2009)

21. F. Dong, C. Jian, F. Zhenghao, G. Kai, L. Zuliang, Catal. Commun. 9, $1924,(2008)$

22. G. Romanelli, G. Pasquale, Á. Sathicq, H. Thomas, J. Autino, P. Vázquez, J. Mol. Catal. A: Chem. 340, 24, (2011)
23. M. M. Khodaei, K. Bahrami, M. Khedri, J. Chin. Chem. Soc. 54, 807, (2007)

24. E. Rafiee, S. Eavani, S. Rashidzadeh, M. Joshaghni, Inorg. Chim. Acta 362, 3555, (2009)

25. N. Iranpoor, F. Kazemi, Tetrahedron 54, 9475, (1998)

26. O. Petrov, Y. Ivanova, M. Gerova, Catal. Commun. 9, 315, (2008)

27. A. George, H. J. Roth, Tetrahedron Lett. 4057, (1971)

28. S. Z. Vatsadze, M. A. Manaenkova, N. V. Sviridenkova, N. V. Zyk, D. P. Krutko, A. V. Churakov, M. Y. Antipin, J. A. K. Howard, H. Lange, Russ. Chem. Bull. Int. Ed. 55, 1184, (2006)

29. A. Modzelewska, C. Pettit, G. Achanta, N. E. Davidson, P. Huang, S. R. Khan, Bioorg. Med. Chem. 14, 3491, (2006) 